\title{
Multiple resistance to glyphosate and imazethapyr in Bidens subalternans
}

\section{Resistência múltipla a glyphosate e imazethapyr em Bidens subalternans}

\author{
Rafael Romero Mendes ${ }^{1 *}\left(\right.$ D) , Fernando Storniolo Adegas ${ }^{2}$ (D), Hudson Kagueyama Takano ${ }^{3}$ (D), \\ Vanessa Francieli Vital Silva' ${ }^{1}$, Fellipe Goulart Machado ${ }^{1}$ (D), Rubem Silvério de Oliveira Junior ${ }^{1}$
}

'Universidade Estadual de Maringá/UEM, Maringá, PR, Brasil

${ }^{2}$ Empresa Brasileira de Pesquisa Agropecuária/Embrapa, Embrapa Soja, Londrina, PR, Brasil

${ }^{3}$ Colorado State University, Fort Collins, Colorado, United States of America

*Corresponding author: rafaromero.mendes@gmail.com

Received in April 18, 2019 and approved in August 07, 2019

\begin{abstract}
Glyphosate has been widely used to control greater beggarticks populations that are resistant to acetolactate synthase (ALS) inhibitors in South America. However, herbicide control failures has been observed over the last three growing seasons in grain production areas of Paraguay. In this research, we report the first case of multiple resistance to glyphosate (EPSPS) and imazethapyr (ALS) in greater beggarticks (Bidens subalternans) population from Paraguay. This conclusion was supported by dose-response experiments conducted in two consecutive years (2018 and 2019) with a putative resistant (R) and a susceptible (S) population. Alternative herbicides were also tested for post-emergence control of R population. For glyphosate, the resistant factor (RF) values were 8.8- (2018) and 15.7-fold (2019). For imazethapyr, the RF values were 59- and 58-fold, in 2018 and 2019, respectively. Treatments with 2,4-D, dicamba, 2,4-D + glyphosate, dicamba + glyphosate, lactofen, fomesafen, ammonium-glufosinate, atrazine, and bentazon provided more than $80 \%$ control of the $\mathrm{R}$ population. This is the first case of multiple resistance to glyphosate and imazethapyr in greater beggarticks (Bidens subalternans) in the world. The mechanisms underlying resistance in this biotype should be evaluated in future research.
\end{abstract}

Index terms: Greater beggarticks; EPSPS inhibitor; ALS inhibitors; chemical control.

\section{RESUMO}

O glyphosate vem sendo amplamente utilizado para o controle de populações de picão-preto resistentes a inibidores da acetolactato sintase (ALS) na América do Sul. No entanto, falhas de controle foram observadas no campo nas três últimas safras em áreas de produção de grãos no Paraguai. Neste trabalho, nós relatamos o primeiro caso de resistência múltipla a glyphosate (EPSPS) e imazethapyr (ALS) em uma população de picão-preto (Bidens subalternans) do Paraguai. Esta conclusão foi sustentada em experimentos de dose-resposta conduzidos em dois anos consecutivos (2018 e 2019) com uma população suspeita de resistência (R) e outra suscetível (S). Herbicidas alternativos também foram avaliados para o controle da população R em pós-emergência. Para o glyphosate, o fator de resistência (FR) foram 8 e 10 em 2018 e 2019, respectivamente. Para imazethapyr, os valores de FR foram 59 (2018) e 58 (2019). Tratamentos com 2,4-D, dicamba, 2,4-D + glyphosate, lactofen, fomesafen, glufosinato de amônio, atrazine e bentazon proporcionaram mais de $80 \%$ de controle da população R. Este é o primeiro relato de resistência múltipla a glyphosate e imazethapyr em picão-preto (Bidens subalternans) no mundo. O mecanismo de resistência neste biótipo deve ser avaliado nas próximas pesquisas.

Termos para indexação: Picão-preto; inibidor da EPSPS; inibidores da ALS; controle químico.

\section{INTRODUCTION}

Glyphosate targets the shikimate pathway, causing plant death through 5-enolpyruvylshikimate-3-phosphate synthase (EPSPS) enzyme inhibition (Duke; Powles, 2008). Glyphosate is a non-selective, systemic and lowcost herbicide widely used in different crop production systems (Heap; Duke, 2018). The frequency in glyphosate use significantly increased after the commercialization of glyphosate-resistant (GR) crops, leading to the evolution of 43 unique GR cases (Heap, 2019). In South America, 17 species have been identified as GR, including 9 mono- and 8 dicotyledonous species (Heap, 2019).

Acetolactate synthase (ALS) inhibiting herbicides are normally sprayed in low rates, have broad spectrum, low toxicity for humans, and are selective to many crops (Yu; Powles, 2014). These herbicides are toxic to plants by inhibiting valine, leucine, and isoleucine amino acids production. Weeds normally evolve resistance to ALS inhibitors more rapidly than to other herbicides probably 
due to the high frequency of target site mutations affecting herbicide binding to the enzyme also due to herbicide metabolization by P450 monooxygenases enzymes (Pretson; Powles, 2002). Likewise, the number of weeds that are resistant to ALS inhibitors is greater than any other herbicide group (Heap, 2014).

Species belonging to the genus Bidens L. (Asteraceae), usually known as beggarticks, are widespread across South American areas in tropical and subtropical environments, infesting roadsides and agricultural crops (Grombone-Guaratini; Solferini; Semir, 2004). In grain fields, greater beggarticks interference with density of more than 40 plants $\mathrm{m}^{-1}$ can cause up to $34 \%$ in yield losses (Galon et al., 2016). While the genus Bidens is composed by many species, only two of them are considered important weeds: Bidens subalternans and B. pilosa (Grombone-Guaratini; Solferini; Semir, 2004). These two species share high levels of morphological similarities, but they can be differentiated by the number of seed awns, 2 to 3 in B. pilosa and 3 to 4 in B. subalternans, and the type of leaf branches in the third top of the plants, dichotomous in B. pilosa and alternates in B. subalternans (Kissmann; Groth, 2000).

Bidens species have a long herbicide resistance history in South Amarica. The first case was reported in B. pilosa resistant to ALS inhibitors infesting soybean fields in the beginning of 1990's (Christoffoleti, 2002). Then, B. subalternans was also identified as resistant to ALS inhibitors in the other soybean crop in 1996. (Lamego et al., 2009). Multiple resistance to ALS inhibitors and atrazine has also been reported for both species in doublecrop soybean/corn fields in Brazil (Takano et al., 2016; Heap, 2019). More recently, GR B. pilosa was reported in México (Cruz et al., 2016).

Over the last three growing seasons, growers have reported greater beggarticks (Bidens subalternans) survival after glyphosate treatment in soybean and corn areas in Paraguay. Considering that extensive soybean and corn fields areas are infested with greater beggarticks resistant to ALS inhibitors (Mendes et al., 2019), it is possible that some populations have been selected for multiple resistance (glyphosate and ALS inhibitors) in these areas. Therefore, our objective was to investigate multiple resistance to EPSPs- and ALS- inhibitors in a putative resistant greater beggarticks population from Paraguay, and evaluate alternative herbicides to chemical control for that population.

\section{MATERIAL AND METHODS}

Greater beggarticks (B. subalternans) seeds were collected in January 2017, in a soybean field at Santa

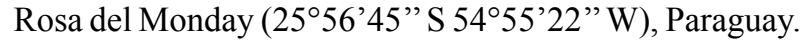
The species was confirmed as B. subalternans due to morphological characteristics. The sampled field had previous history of soybean in the fall/summer followed by corn in the autumn/winter and the area had been sprayed with glyphosate for at least 10 years in soybean and five years in corn. Seeds were sampled from 20 random plants that survived glyphosate application. Subsequently, seeds were cleaned, stored in paper bags, identified and kept in room temperature until the experiments were conducted.

Seeds were sowed in 200-cell flats $(1 \times 1 \times 3 \mathrm{~cm})$ filled with potting soil (MacPlant $\left.{ }^{\mathbb{R}}\right)$. After germination, seedlings were transplanted to $1 \mathrm{dm}^{3}$ pots filled with soil ( $27 \%$ clay, pH 6.2 and organic matter $2.1 \%$ ) and potting soil at 1:1 ratio. Thirty plants (three-leaf stage, 10-12 $\mathrm{cm}$ height) were sprayed with glyphosate at $960 \mathrm{~g}$ ae ha $^{-1}$ (Roundup Transorb $\mathrm{R}^{\circledR}, 2 \mathrm{~L} \mathrm{ha}^{-1}$ ) and imazethapyr at $106 \mathrm{~g}$ ai ha- ${ }^{-1}$ (Zethapyr ${ }^{\circledR} 1,0 \mathrm{~L} \mathrm{ha}^{-1}$ ) in a tank mix. After application of both herbicides, surviving plants were kept in pots to produce seeds. Flats and pots were kept under greenhouse conditions with daily irrigation of $5 \mathrm{~mm}$. Seeds from treated plants (F1) were collected and stored as previously described.

Dose-response experiments were conducted with the $\mathrm{F} 1$ generation of putative resistant $(\mathrm{R})$ and another population previously determined as susceptible (S) collected at Maringá (PR). Plant growth conditions were conducted as describe above. One experiment was designed for each herbicide in a $2 \times 8$ factorial (two populations and eight herbicide doses). Glyphosate was applied at $0,120,240,480,960,1920$ and $3840 \mathrm{~g}$ ae ha ${ }^{-1}$ on $\mathrm{S}$ and at 0, 240, 480, 960, 1920, 3840 and $7680 \mathrm{~g}$ ae ha- $^{-1}$ on $\mathrm{R}$ population. For imazethapyr, $\mathrm{S}$ and $\mathrm{R}$ were treated with $0,13.2,26.5,53,106,212,424$ and $848 \mathrm{~g}$ ai ha ${ }^{-1}$. The label dose for $B$. pilosa used as field dose for B. subalternans control is 480-720 $\mathrm{g}$ ae ha ${ }^{-1}$ for glyphosate and $106 \mathrm{~g}$ ai $\mathrm{ha}^{-1}$ for imazethapyr. The treatments were applied on plants at the three-leaf stage $(10-12 \mathrm{~cm})$, and the experimental design was completely randomized with four replications. Dose-response experiments were conducted in 2018 and repeated in 2019.

An additional experiment was conducted to evaluate the efficacy of alternative herbicides on the $\mathrm{R}$ population. Plants were grown in the greenhouse as described above. Different herbicides that are currently recommended for greater beggarticks control in soybeans and corn post emergence were evaluated (Rodrigues; Almeida, 2018). The treatments were: untreated check; 2,4-D at $670 \mathrm{~g}$ ae ha ${ }^{-1}\left(\mathrm{DMA}^{\circledR}, 1 \mathrm{~L} \mathrm{ha}^{-1}\right)$; dicamba at 480 g ae ha ${ }^{-1}\left(\right.$ Atectra $\left.^{\circledR}, 1 \mathrm{~L} \mathrm{ha}^{-1}\right) ; 2,4-\mathrm{D}+$ glyphosate at $608+$ 
$960 \mathrm{~g}_{\text {ae ha }}{ }^{-1} ;$ dicamba + glyphosate at $480+960 \mathrm{~g}$ ae ha ${ }^{-1}$; lactofen at $180 \mathrm{~g}$ ai ha $^{-1}\left(\mathrm{Naja}^{\mathbb{B}}, 0.75 \mathrm{~L} \mathrm{ha}^{-1}\right)$; fomesafen 250 g ai ha ${ }^{-1}\left(\right.$ Flex $\left.^{\circledR} 1 \mathrm{~L} \mathrm{ha}^{-1}\right)$; ammonium-glufosinate at 400 ai $\mathrm{g} \mathrm{ha}^{-1}\left(\right.$ Finale $\left.^{\circledR}, 2 \mathrm{~L} \mathrm{ha}^{-1}\right)$; chlorimuron-ethyl at $20 \mathrm{~g}$ ai ha ${ }^{-1}$ $\left(\right.$ Classic $\left.^{\circledR}, 80 \mathrm{~g} \mathrm{ha}^{-1}\right)$, atrazine at $1,500 \mathrm{~g}^{2}$ ha $^{-1}$ (Proof $^{\circledR}, 3$ $\left.\mathrm{L} \mathrm{ha}^{-1}\right)$; mesotrione at $144 \mathrm{~g}^{\text {ai ha }}{ }^{-1}\left(\right.$ Callisto $^{\circledR}, 0.3 \mathrm{~L} \mathrm{ha}^{-1}$ ); tembotrione at $76 \mathrm{~g}$ ai ha ${ }^{-1}\left(\operatorname{Soberan}^{\circledR}, 0.18 \mathrm{~L} \mathrm{ha}^{-1}\right)$ and bentazon at $720 \mathrm{~g}$ ai ha ${ }^{-1}\left(\right.$ Basagran $\left.^{\circledR}, 1.2 \mathrm{~L} \mathrm{ha}^{-1}\right)$. Adjuvants were added following the label of each herbicide.

All applications were performed with a $\mathrm{CO}_{2}$ pressurized backpack sprayer and a $1.5 \mathrm{~m}$ long bar with three ST 100.02 spray nozzles $(0.5 \mathrm{~m}$ between nozzles, Teejet Technologies $\left.{ }^{\circledR}\right)$. The sprayer was operated at 195 $\mathrm{kpa}$, providing a spray volume of $150 \mathrm{~L} \mathrm{ha}^{-1}$. For all experiments, plant survival was evaluated following a $0-100 \%$ scale, in which zero means plant death and $100 \%$ means no visual symptoms. At the end of each experiment, shoots were collected and dried at $60{ }^{\circ} \mathrm{C}$ for four days and dry mass was measured. Evaluations were performed at 21 days after treatment (DAT) for dose-response experiments and at 14 and 28 DAT for the alternative chemical control experiment.

Dose-response data from each year (2018 and 2019) were subjected to ANOVA $(\mathrm{p}<0.05)$ and then to a combined analysis with multiple years for each herbicide. Non-linear regression models with four (glyphosate Equation 1) or three parameters (imazethapyr - Equation 2) were fit using SigmaPlot 12 software.

$$
\begin{aligned}
& \hat{y}=d+\frac{a-d}{1+\left(\frac{x}{c}\right)^{b}} \\
& \hat{y}=\frac{a}{1+\left(\frac{x}{c}\right)^{b}}
\end{aligned}
$$

Where $a$ is the upper limit, $b$ is the slope around $c, c$ is the dose to $50 \%$ of plant survival or dry mass relative to untreated check (relative dry mass) and $d$ is the lower limit. The $x$ values were independent (dose) and $y$ values were dependent (survival or dry mass) variables. After models adjustment, the dose for $50 \%$ of survival $\left(\mathrm{LD}_{50}\right)$ and the dose for $50 \%$ of relative dry mass $\left(\mathrm{ED}_{50}\right)$ were calculated through inverse equation, by using $x$ as a function of $y$ (Ritz et al., 2015). Resistant factors (RF) were obtained using $\mathrm{LD}_{50} \mathrm{R} / \mathrm{S}$ or $\mathrm{ED}_{50} \mathrm{R} / \mathrm{S}$ ratio. For the alternative control experiment, data were subjected to ANOVA $(\mathrm{p}<0.05)$ and Tukey test $(p<0.05)$ were used to compare means. Both analyses were ran using SISVAR 12 software (Ferreira, 2011).

\section{RESULTS AND DISCUSSION}

There was a significant interaction $(\mathrm{p}<0.05)$ between the two years of experiments for glyphosate and imazethapyr in all variables, therefore, the dose-response curves were fit separately for each year (2018 and 2019).

For glyphosate, $\mathrm{LD}_{50}$ value was higher in $\mathrm{R}$ than in $\mathrm{S}$ population. The $\mathrm{R}$ population was 8.8 -fold (2018) and 15.7-fold (2019) more resistant than $\mathrm{S}$, based on the RF values (Figure 1). To achieve efficient control $(\leq 10 \%$ survival) on the $\mathrm{R}$ population, it would be necessary $4,850 \mathrm{~g} \mathrm{e} \mathrm{ha}^{-1}$ based on the data from 2018. On the other hand, even the highest dose tested $\left(7,680 \mathrm{~g}\right.$ ae ha $\left.\mathrm{h}^{-1}\right)$ was not enough to provide less than $21 \%$ survival in 2019 . Labeled rates of glyphosate for greater beggarticks range from 480 to $960 \mathrm{~g}$ ae ha ${ }^{-1}$ (Rodrigues; Almeida, 2018), which emphasizes the resistance to glyphosate in the $\mathrm{R}$ population (Table 1$)$. Dry mass $\left(\mathrm{ED}_{50}\right)$ values provided $\mathrm{RF}$ of 10- (2018) and 22-fold (2019) (Figure 1 and Table 1), which is in agreement with the survival data.

For hairy beggarticks (B. pilosa), a closely related species, glyphosate resistance levels based on $\mathrm{ED}_{50}(20.4-$ fold) were very similar to ours (Cruz et al., 2016). High RF levels in glyphosate resistance $(>10)$ has also been found in other dicotyledonous weeds, such as Conyza sumatrensis (Santos et al., 2014) and Amaranthus palmeri (Gonçalves Netto et al., 2016).

The $\mathrm{R}$ population demonstrated significant resistance levels to imazethapyr (Figure 2). The $\mathrm{R}$ population was 59.4-fold (2018) and 58.7-fold (2019) more resistant than $\mathrm{S}$ based on survival. Based on the $\mathrm{ED}_{50}$, these values were 24.2-fold in 2018 and 32.4-fold in 2019 (Table 2). In both years, survival levels were $\geq 62 \%$ for $\mathrm{R}$, and the calculated dose of imazethapyr to provide $\leq 10 \%$ survival exceeded the highest dose applied $(>848$ $\mathrm{g}$ ai ha $\left.{ }^{-1}\right)$. The results found here are similar to the RF range found for ALS inhibitors in other B. subalternans populations from South America (Lamego et al., 2009; Mendes et al., 2019).

Prior to the GR crops era, ALS inhibitors were often used for weed control in pre- and post-emergence, contributing to the selection pressure and evolution of resistant populations around the world (Green, 2014). After the introduction of GR crops, the selection pressure imposed by glyphosate applications increased substantially 
on plants that were already resistant to ALS inhibitors, leading to the evolution of multiple resistant weeds (Heap and Duke, 2018). Similar to greater beggarticks, other weeds have already been identified with multiple resistance to glyphosate and ALS inhibitors, such as $A$. palmeri (Gonçalves Netto et al., 2016), Lolium rigidum (Owen et al., 2007), C. sumatrensis (Santos et al., 2014) and Kochia scoparia (Beckie et al., 2013).
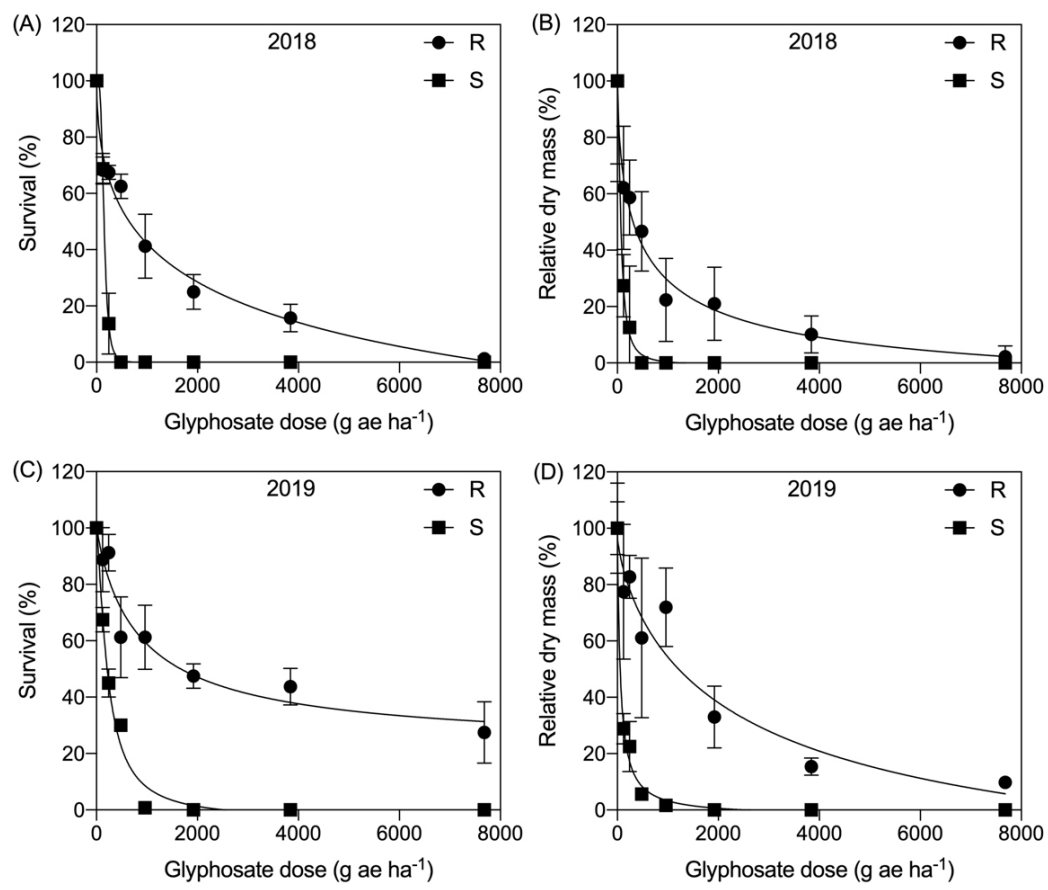

Figure 1: Dose-response curves for glyphosate in greater beggarticks (Bidens subalternans). Circles represent the resistant (R) population and squares represent the susceptible (S) population. Bars represent standard errors. Model fit: Plant survival or relative dry mass $=d+\left[a-d / 1+(\text { dose } / c)^{b}\right]$.

Table 1: Model parameters, dose in $g$ ae ha-1 to provide $50 \%$ of plant survival $\left(L_{50}\right)$, dose to provide $50 \%$ of relative dry mass $\left(\mathrm{ED}_{50}\right)$, and resistant factor (RF) in greater beggarticks (Bidens subalternans) resistant (R) and susceptible (S) to glyphosate.

\begin{tabular}{|c|c|c|c|c|c|c|c|c|}
\hline Variable & Population & $a$ & $b$ & c & $d$ & $\mathrm{R}^{2}$ & $\mathrm{LD}_{50}$ or $\mathrm{ED}_{50^{1 /}}$ & $\mathrm{RF}^{2}$ ' \\
\hline & \multicolumn{8}{|c|}{2018} \\
\hline \multirow{2}{*}{ Survival } & $\mathrm{R}$ & 169.1 & 0.5 & $3,856.5$ & -69.7 & 0.98 & 650 & \multirow{2}{*}{8.8} \\
\hline & $S$ & 100.2 & 3.8 & 74 & -0.2 & 0.99 & 73.8 & \\
\hline \multirow{2}{*}{$\begin{array}{l}\text { Relative dry } \\
\text { mass }\end{array}$} & $\mathrm{R}$ & 113.9 & 0.6 & 466.8 & -14.1 & 0.98 & 312 & \multirow{2}{*}{10} \\
\hline & $S$ & 100.7 & 1.7 & 34.7 & -0.7 & 0.99 & 31.2 & \\
\hline & \multicolumn{8}{|c|}{2019} \\
\hline \multirow{2}{*}{ Survival } & $\mathrm{R}$ & 79.4 & 0.9 & 868.4 & 21.6 & 0.94 & 1665.1 & \multirow{2}{*}{15.7} \\
\hline & $S$ & 102.7 & 1.4 & 112.2 & -3.4 & 0.98 & 106.1 & \\
\hline \multirow{2}{*}{$\begin{array}{l}\text { Relative dry } \\
\text { mass }\end{array}$} & $\mathrm{R}$ & 135.0 & 0.4 & $2,906.8$ & -37.7 & 0.66 & 610 & \multirow{2}{*}{22.1} \\
\hline & S & 102.1 & 1.0 & 28.8 & -2.18 & 0.99 & 27.6 & \\
\hline
\end{tabular}



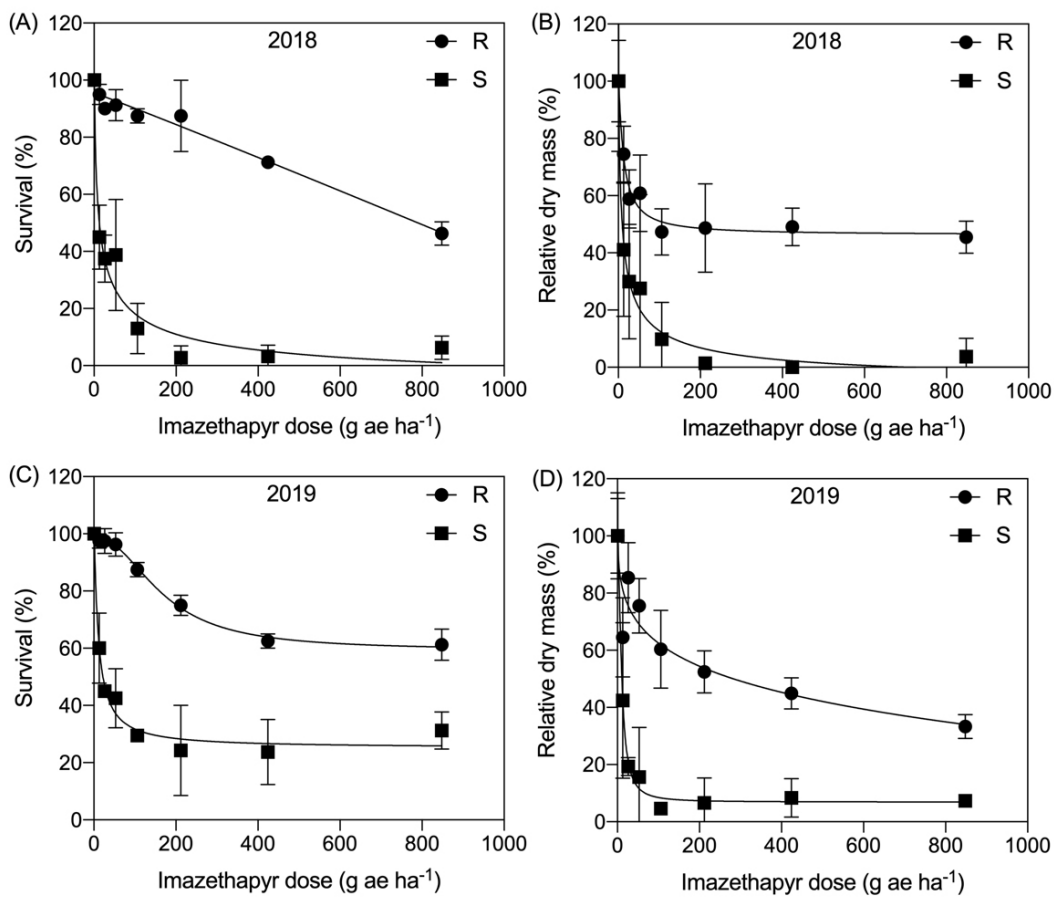

Figure 2: Dose-response curves for imazethapyr in greater beggarticks (Bidens subalternans). Circles represent the resistant (R) population and squares represent the susceptible (S) population. Bars represent standard errors. Model fit: Plant survival or relative dry mass $=a / 1+(\text { dose } / c)^{b}$.

Table 2: Model parameters, dose in $g$ ae ha-1 to provide $50 \%$ of plant survival $\left(L_{50}\right)$, dose to provide $50 \%$ of relative dry mass $\left(E D_{50}\right)$, and resistant factor (RF) in greater beggarticks (Bidens subalternans) resistant $(\mathrm{R})$ and susceptible (S) to imazethapyr.

\begin{tabular}{ccrrrrrr}
\hline Variable & Population & \multicolumn{1}{c}{$a$} & \multicolumn{1}{c}{$c$} & \multicolumn{1}{c}{$c$} & $\mathrm{R}^{2}$ & $\mathrm{LD}_{50}$ or $\mathrm{ED}_{50}{ }^{1 /}$ & $\mathrm{RF}^{2 \prime}$ \\
\hline \multirow{2}{*}{ Survival } & $\mathrm{R}$ & 94.1 & 1.6 & 841.2 & 0.96 & 778.9 & \multirow{2}{*}{59.4} \\
& $\mathrm{~S}$ & 99.5 & 0.7 & 13.3 & 0.96 & 13.1 & \\
Relative dry & $\mathrm{R}$ & 100.4 & 0.2 & 231.8 & 0.93 & 236 & 24.2 \\
mass & $\mathrm{S}$ & 99.8 & 0.8 & 9.8 & 0.98 & 9.7 & \\
\hline \multirow{2}{*}{ Survival } & $\mathrm{R}$ & 102.3 & 0.7 & $1,123.2$ & 0.94 & $1,196.9$ & \multirow{2}{*}{58.7} \\
\multirow{2}{*}{$\begin{array}{c}\text { Relative dry } \\
\text { mass }\end{array}$} & $\mathrm{S}$ & 100.4 & 0.3 & 19.9 & 0.95 & 20.4 & \\
& $\mathrm{R}$ & 97.5 & 0.5 & 298 & 0.87 & 269 & 32.4 \\
\hline
\end{tabular}

Model fitted parameters: Survival or relative dry mass $=a / 1+(\text { dose } / c)^{b} ;{ }^{1 /}$ calculated by inverse equation; ${ }^{2} / D_{50} R / S$ or $E D_{50} R / S$ ratio.

Resistance to glyphosate in weeds has been associated with both target-site (TSR) and non-targetsite (NTSR) mechanisms. Target site mutations by single nucleotide polymorphisms are known to confer resistance by changing the enzyme structure, which prevents glyphosate from binding to EPSPS (Sammons; 
Gaines, 2014). Another TSR mechanism is the capacity of resistant biotypes to produce more copies of the EPSPS gene compared to susceptible plants, making glyphosate rates insufficient to inhibit the increased enzyme number (Gaines et al., 2010; Wiersma et al., 2015). NTSR mechanisms are often found in weeds and they are normally associated with reduced uptake and translocation, enhanced metabolism, vacuolar sequestration and/or rapid tissue death (Sammons; Gaines, 2014; Moretti et al., 2018). Usually, single mutations in positions Thr-102 or Pro-106 of EPSPS do not result in high RF values (Han et al., 2016). On the other hand, the simultaneous presence of Thr-102Ile and Pro-106-Leu in resistant plants (TIPS mutation) confer much higher RF values (more than 100-fold) (Yu et al., 2015). The increase in EPSPS copy number and NTS mechanisms also can lead to high RF to glyphosate in weeds (Gaines et al., 2010). In the hairy beggarticks population resistant to glyphosate from México, Cruz et al. (2016) found a Pro-106-Leu in one population and the TIPS mutation in another population, providing RF of 2.4 and 20.7, respectively.

Recently, the mechanism of resistance in a GR $B$. subalternans from Paraguay was under investigation and the double mutation TIPT (Thr-102-Ile and Pro-106-Thr) was found in one EPSPs allele of two EPSPs homologous in this species (Takano et al., 2019).

Resistance to ALS inhibitors has been widely studied for a long time. Mutations in $A L S$ is the most common mechanism and can occur in eight different amino acids positions of the gene (Heap, 2019). Typically, mutations that result in the highest RF for imidazolinones, such as imazethapyr, are described in Ala-122, Ala-205 and Trp-574 (Powles; Yu, 2014; Heap, 2019). The Trp-574Leu substitution has been found in a greater beggarticks population from Brazil, resulting in 166-fold resistance to imazethapyr (Lamego et al., 2009). More rarely, enhanced metabolism by $\mathrm{P} 450$ monooxygenases enzymes or reduced translocation have also been described in the literature (Guo et al., 2015; Nakka et al., 2017). Investigating herbicide resistance mechanisms to ALS inhibitors in weeds are critical to develop management strategies.

When herbicides were applied on plats at the three-leaf stage (10-12 $\mathrm{cm}$ height), most treatments provided good performance on the $\mathrm{R}$ population, except chlorimuron-ethyl, mesotrione and tembotrione (Table 3). We have not conducted a dose response for other ALS inhibitors herbicides, but these results suggest that the $\mathrm{R}$ population could be cross-resistant to other herbicides

Table 3: Efficacy of alternative herbicides to control glyphosate- and imazethapyr-resistant greater beggarticks (Bidens subalternans) in post-emergence.

\begin{tabular}{|c|c|c|c|c|}
\hline \multirow{2}{*}{ Treatment } & \multirow{2}{*}{$\begin{array}{l}\text { Dose } \\
\left(\mathrm{g} \mathrm{ha}^{-1}\right)\end{array}$} & \multicolumn{2}{|c|}{ Survival (\%) } & \multirow{2}{*}{$\begin{array}{c}\text { Relative } \\
\text { dry mass (\%) }\end{array}$} \\
\hline & & $14 \mathrm{DAT}$ & 28 DAT & \\
\hline Untreated check & - & $100 \mathrm{a}$ & 100 a & $100 \mathrm{a}$ \\
\hline $2,4-D$ & $670^{1 /}$ & $20 \mathrm{~d}$ & $0.7 \mathrm{e}$ & $0.01 \mathrm{~d}$ \\
\hline Dicamba & $480^{1 /}$ & $24 \mathrm{~d}$ & $0.7 \mathrm{e}$ & $0.01 \mathrm{~d}$ \\
\hline 2,4-D + glyphosate & $670+960^{1 /}$ & $20 \mathrm{~d}$ & $1 \mathrm{e}$ & $0.01 \mathrm{~d}$ \\
\hline Dicamba + glyphosate & $480+960^{1 /}$ & $20 \mathrm{~d}$ & $0.7 \mathrm{e}$ & $0.01 \mathrm{~d}$ \\
\hline Lactofen & 180 & $0.2 \mathrm{e}$ & $0 \mathrm{e}$ & $0 \mathrm{~d}$ \\
\hline Fomesafen & 250 & $0.2 \mathrm{e}$ & $0 \mathrm{e}$ & $0 \mathrm{~d}$ \\
\hline Ammonium-glufosinate ${ }^{2 /}$ & 400 & $2.2 \mathrm{e}$ & $0 \mathrm{e}$ & $0 \mathrm{~d}$ \\
\hline Chlorimuron-ethyl²' & 20 & $77 \mathrm{~b}$ & $56 \mathrm{c}$ & $28 \mathrm{c}$ \\
\hline Atrazine ${ }^{3 /}$ & 1,500 & $1.2 \mathrm{e}$ & $0 \mathrm{e}$ & $0 \mathrm{~d}$ \\
\hline Mesotrione ${ }^{3 /}$ & 144 & $51 \mathrm{c}$ & $34 d$ & $6 \mathrm{~d}$ \\
\hline Tembotrione ${ }^{3 /}$ & 76 & $59 \mathrm{c}$ & $88 \mathrm{~b}$ & $40 \mathrm{~b}$ \\
\hline Bentazon ${ }^{3 /}$ & 720 & $0.7 \mathrm{e}$ & $0 \mathrm{e}$ & $0 \mathrm{~d}$ \\
\hline
\end{tabular}

Means followed by the same letters indicates no difference by Tukey's test $(\mathrm{P}<0.05) ;{ }^{1 / d}$ dose in $\mathrm{g}$ ea; ${ }^{2 /}$ applied with non-ionic surfactant at $0,2 \% \mathrm{v} \mathrm{v}^{-1} ;$ ㄱaㄹ applied with mineral oil at $0,5 \% \mathrm{v} \mathrm{v}^{-1}$; DAT: days after treatment. 
in this class, consistent with what has been described in other greater beggarticks populations across South America (Lamego et al., 2009; Mendes et al., 2019). For HPPD-inhibiting herbicides (mesotrione and tembotrione), frequently used in corn fields, their tank mix with atrazine can provide efficient greater beggarticks control (Matte et al., 2018). Despite the levels of control observed with PSII inhibitors (atrazine and bentazon), atrazine resistance has already been reported in this species (Heap, 2019), than, careful recommendations should be made for the sustainable use of PSII herbicides.

Treatments containing 2,4-D, dicamba, and ammonium-glufosinate are important options for burndown weed control and will probably be even more important with the launch of new herbicide tolerance traits in South America, such as Enlist ${ }^{\circledR}$, Xtend $^{\circledR}$ and Liberty Link ${ }^{\circledR}$. The results provide evidence that at least four different $\mathrm{MoA}$ are still effective on the $\mathrm{R}$ greater beggarticks population (synthetic auxins, protoporphyrinogen-oxidase (PPO)inhibitors, PSII- inhibitors and glutamine-synthetase (GS)-inhibitor) (Table 3). Other options in pre-emergence that were not evaluated in this research may also provide tools to improve greater beggarticks management (e.g. sulfentrazone and flumioxazin) (Lopez Ovejero et al., 2013). Herbicide rotation with different MoAs is essential to prevent and manage multiple resistance evolution. More importantly, additional non-chemicals practices should also be included in weed management strategies, such as crop rotation, cover crops, mechanical and cultural control (Marochi et al., 2018). Thus, machinery cleaning is another important measure to prevent the spread of this problem (Takano et al., 2018). Finally, survey programs should be implemented to monitor the eventual spread of glyphosate R populations of greater beggarticks towards other countries.

\section{CONCLUSIONS}

This research confirmed the first case of glyphosate resistance in greater beggarticks (Bidens subalternans) worldwide. This population is also resistant to imazethapyr. Alternative herbicides from at least four different MoA, applied in post-emergence, demonstrated efficient control of this multiple resistant greater beggarticks population.

\section{ACKNOWLEDGMENTS}

Fabrício Kzryaniak who has reported control failures of greater beggarticks and has collected seeds at the field. CAPES which funded sources to students those conducted this research.

\section{REFERENCES}

BECKIE, H. J. et al. Glyphosate-and acetolactate synthase inhibitor-Resistant Kochia (Kochia scoparia) in Western Canada. Weed Science, 62(1):310-318, 2013.

CHRISTOFFOLETI, P. J. Curvas de dose-resposta de biótipos resistente e suscetível de Bidens pilosa $\mathrm{L}$. aos herbicidas inibidores da ALS. Scientia Agricola, 68(3):613-619, 2002.

CRUZ, R. A. et al. Target and non-target site mechanisms developed by glyphosate-resistant hairy beggarticks (Bidens pilosa L.) populations from Mexico. Frotiers in Plant Science, 7(1):1-12, 2016.

DUKE, S. O.; POWLES, S. B. Glyphosate: A-once-in-century herbicide. Pest Management Science, 64(2):319-325, 2008.

FERREIRA, D. F. Sisvar: A computer statistical analysis system. Ciência e Agrotecnologia, 35(6):1035-1042, 2011.

GAINES, T. A. et al. Gene amplification confers glyphosate resistance in Amaranthus palmeri. Proceedings of the National Academy of Sciences, 107(3):1029-1034, 2010.

GALON, L. et al. Interference and economic threshold level for control of beggartick on bean cultivares. Planta Daninha, 34(3):411-422, 2016.

GONÇALVES NETTO, A. et al. Multiple resistance of Amaranthus palmeri to ALS and EPSPS inhibiting herbicides in the State of Mato Grosso, Brazil. Planta Daninha, 34(3):581-587, 2016.

GREEN, J. M. Current state of herbicides in herbicide-resistant crops. Pest Management Science, 70(2):1351-1357, 2014.

GROMBONE-GUARATINI, M. T.; SOLFERINI, V. N.; SEMIR, J. Reproductive biology in species of Bidens L. (Asteraceae). Scientia Agricola, 61(2):185-189, 2004.

GUO, J. et al. Nontarget-site resistance to ALS inhibitors in waterhemp (Amaranthus tuberculatus). Weed Science, 63(2):399-407, 2015.

HAN, H. et al. Target-site EPSPS Pro-106 mutations: Sufficient to endow glyphosate resistance in polyploidy Echinochloa colona? Pest Management Science, 72(2):264-271, 2016

HEAP, I. Global perspective of herbicide-resistant weeds. Pest Management Science, 70(9):1306-1315, 2014.

HEAP, I. International survey of herbicide resistant weeds. Weed Science. 2019. Available in: <http://weedscience. org/>. Access in March 28, 2019. 
HEAP, I.; DUKE, S. O. Overview of glyphosate-resistant weeds worldwide. Pest Management Science, 74(11):1040-1049, 2018.

KISSMANN, K. G.; GROTH, D. Plantas Infestantes e nocivas. $2^{a}$ ed. BASF: São Paulo, 2000, 726p.

LAMEGO, F. P. Molecular basis of resistance to ALS-inhibitor herbicides in Greater beggarticks. Weed Science, 57(1):474481, 2009.

LOPEZ OVEJERO, R. F. et al. Residual herbicides in weed management for glyphosate-resistant soybean in Brazil. Planta Daninha, 31(4):947-959, 2013.

MAROCHI, A. F. A. et al. Managing glyphosate-resistant weeds with cover crop associated with herbicide rotation and mixture. Ciência e Agrotecnologia, 42(4):381-394, 2018.

MATTE, W. D. et al. Eficácia de atrazine + mesotrione para o controle de plantas daninhas na cultura do milho. Revista Brasileira de Herbicidas, Available in: April , 2018. < http:// dx.doi.org/10.7824/rbh.v17i2.587>. Access in: 2019.

MENDES, R. R. et al. Identification and mapping of crossresistance patterns to ALS-inhibitors in greater beggarticks (Bidens spp.). Planta Daninha, e019192481, 2019.

MORETTI, M. L. Glyphosate resistance in Ambrosia trifida: Part 2. Rapid response physiology and non-target-site resistance. Pest Management Science, 74(5):1079-1088, 2018.

NAKKA, S. et al. Target site-based and non-target site based resistance to ALS inhibitors in palmer amaranth (Amaranthus palmeri). Weed Science, 65(6):681-689, 2017.

OWEN, M. J. et al. Widespread occurrence of multiple herbicide resistance in Western Australian annual ryegrass (Lolium rigidum) populations. Australian Journal of Agricultural Research, 58(7):711-718, 2007.

PRETSON, C.; POWLES, S. B. Evolution of herbicide resistance in weeds. Initial frequency of target site-based resistance to acetolactate synthase-inhibiting herbicides in Lolium rigidum. Heredity, 8(1):8-13, 2002.

RITZ, C. Dose-response analysis using R. PLOS ONE, Available in: December 30, 2015. < https://doi.org/10.1371/journal. pone.0146021>. Access in: 2019.

RODRIGUES, B. N.; ALMEIDA, F. S. Guia de herbicidas. Londrina: 2018. 764p.

SAMMONS, R. D.; GAINES, T. A. Glyphosate resistance: State of knowledge. Pest Management Science, 70(9):1367-1377, 2014.

SANTOS, G. et al. Multiple resistance of Conyza sumatrensis to chlorimuron-ethyl and to glyphosate. Planta Daninha, 32(2):409-416, 2014.

TAKANO, H. K. et al. A novel TIPT double mutation in EPSPs conferring glyphosate resistance in tetraploid Bidens subalternans. Pest Management Science, Available in: August,12, 2019. <https://doi.org/10.1002/ps.5535>. Access in: 2019.

TAKANO, H. K. et al. Multiple resistance to atrazine and imazethapyr in hair beggarticks (Bidens pilosa). Ciência e Agrotecnologia, 40(5):547-554, 2016.

TAKANO, H. K. et al. Spread of glyphosate-resistant sourgrass (Digitaria insularis): Independent selections or merely propagule dissemination? Weed Biology and Management, 18(1):50-59, 2018.

WIERSMA, A. T. et al. Gene amplification of 5-enolpyruvylshikimate-3-phosphate synthase in glyphosateresistant Kochia scoparia. Planta, 24(1):463-474, 2015.

YU, Q. et al. Evolution of a double amino acid substitution in the 5-enolpyruvylshikimate-3-phosphate synthase in Eleusine indica conferring high-level glyphosate resistance. Plant Physiology, 167(4):1440-1447, 2015

YU, Q.; POWLES, S. B. Resistance to AHAS inhibitors herbicides: Current understanding. Pest Management Science, 70(1):1340-1350, 2014. 